\title{
Assessment of cutting time on nutrient values, in vitro fermentation and methane production among three ryegrass cultivars
}

\author{
Chunmei Wang ${ }^{1}$, Fujiang Hou ${ }^{1, *}$, Metha Wanapat ${ }^{2}$, Tianhai Yan ${ }^{3}$, Eun Joong Kim ${ }^{4}$ and Nigel David Scollan ${ }^{5}$
}

* Corresponding Author: Fujiang Hou Tel: +86-931-8913047, Fax: +81-931-8910979,

E-mail: cyhoufj@|zu.edu.cn

${ }^{1}$ State Key Laboratory of Grassland Agro-Ecosystems, Key Laboratory of Grassland Livestock Industry Innovation, Ministry of Agriculture and Rural Affairs, College of Pastoral Agriculture Science and Technology, Lanzhou University, Lanzhou 730020, Gansu, China

2 Tropical Feed Resources Research and Development Center (TROFREC), Department of Animal Science, Faculty of Agriculture, Khon Kaen University, Khon Kaen 40002, Thailand

${ }^{3}$ Agri-Food and Biosciences Institute, Hillsborough, Co Down BT26 6DR, United Kingdom

${ }^{4}$ Department of Animal Science, Kyungpook National University, Sangju 37222, Korea

${ }^{5}$ Institute for Global Food Security, Queens University

Belfast, Stranmillis Road, Belfast BT9 5AG, United

Kingdom

ORCID

Chunmei Wang

https://orcid.org/0000-0003-2905-1322

Fujiang Hou

https://orcid.org/0000-0002-5368-7147

Metha Wanapat

https://orcid.org/0000-0002-7633-052X

Tianhai Yan

https://orcid.org/0000-0002-1994-5202

Eun Joong Kim

https://orcid.org/0000-0002-5962-6994

Nigel David Scollan

https://orcid.org/0000-0002-7305-2819

Submitted May 1, 2019; Revised Jul 19, 2019;

Accepted Sept 10, 2019
Objective: The $3 \times 3$ factorial arrangement was used to investigate if either high watersoluble carbohydrates (WSC) cultivars or suitable time of day that the grass cut could improve nutrient values and in vitro fermentation characteristics.

Methods: The 3 cultivars were mowed at 3 diurnal time points and included a benchmark WSC ryegrass cultivar 'Premium', and 2 high WSC cultivars AberAvon and AberMagic, which contained, on average, 157, 173, and $193 \mathrm{~g} / \mathrm{kg}$ dry matter (DM) of WSC, and 36.0, 36.5, and $34.1 \mathrm{~g} / \mathrm{kg} \mathrm{DM}$ of $\mathrm{N}$ during 7 th regrowth stage, respectively. The fermentation jars were run at $39^{\circ} \mathrm{C}$ with gas production recorded and sampled at $2,5,8,11,14,17,22,28,36$, and $48 \mathrm{~h}$. The rumen liquid was collected from 3 rumen fistulated cows grazing on ryegrass pasture. Results: High WSC cultivars had significantly greater WSC content, in vitro DM digestibility (IVDMD) and total gas production (TGP), and lower lag time than Premium cultivar. Methane production for AberMagic cultivar containing lower $\mathrm{N}$ concentration was marginally lower than that for AberAvon and Premium cultivars. Grass cut at Noon or PM contained greater WSC concentration, IVDMD and TGP, and lower N and neutral detergent fiber (NDF) contents, but $\mathrm{CH}_{4}$ production was also increased, compared to grass cut in AM. Meanwhile, the effects of diurnal cutting time were influenced by cultivars, such as in vitro $\mathrm{CH}_{4}$ production for AberMagic was not affected by cutting time. The IVDMD and gas production per unit of DM incubated were positively related to WSC concentration, WSC/N and WSC/NDF, respectively, and negatively related to N and NDF concentrations.

Conclusion: These results imply either grass cut in Noon or PM or high WSC cultivars could improve nutrient values, IVDMD and in vitro TGP, and that AberMagic cultivar has a slightly lower $\mathrm{CH}_{4}$ production compared to AberAvon and Premium. Further study is necessary to determine whether the increase of $\mathrm{CH}_{4}$ production response incurred by shifting from AM cutting to Noon and/or PM cutting could be compensated for by high daily gain from increased WSC concentration and DM digestibility.

Keywords: Diurnal Cutting Time; In vitro Dry Matter Digestibility; Methane; Nitrogen; Water Soluble Carbohydrates

\section{INTRODUCTION}

As one of the most important and common forages for dairy cows in temperate regions [1], ryegrass widely sown for grazing ruminants (Lolium perenne L.) is featured by high forage yield and nutritive value, especially high soluble and degradable $\mathrm{N}$ and carbohydrates [2]. Ruminant production is moving towards rely on more forage or only grass-based diets, but the grass-based system is challenged by the large fluctuation in grass availability and nutrient values affected by seasonal condition and growth period. The quality of grass has effect on nutrient intake and utilization efficiency [3,4], and the problem of poor-quality forages leaded to low microbial protein yield cannot simply be solved or completely compensated by supplementing high amounts of concentrates [5]. It is also revealed that good 
quality grass has the potential to sustain high feeding efficiency similar to concentrates [6], which could reduce farming cost. Hence, identifying the nutritive values of perennial ryegrass is critical for ruminant production system.

Previous studies indicated that increasing water-soluble carbohydrates (WSC) concentration in diets could improve daily live weight gain [7], dry matter (DM) digestibility and milk yield [3,8], reduce $\mathrm{CH}_{4}$ emission per unit of DM intake and live-weight gain [7] by favoring the rumen fermentation with propionate and butyrate production $[8,9]$, and decrease nitrogen excretions especially urinary $\mathrm{N}$ excretion in ruminant farming $[10,11]$ by increasing the capture of ammonia in rumen and utilization efficiency of endogenous $\mathrm{N}$ cycle $[10,12]$ and promoting microbial protein synthesis $[9,13]$. Nutritive values (e.g., WSC) of grass are not only influenced by inherited characteristics such as improved cultivars and genetic selection, but also determined by short physiological responses of the plants to changes in their immediate environment such as diurnal cutting management [3,14]. In rotational grazing systems, cows transformed into a new perennial ryegrass paddock in the evening [15] and/or offered alfalfa cut in PM [3] had greater milk yield. The response of nutrient values to diurnal cutting variations and grass cultivars is necessary to be identified for optimizing grazing management. Furthermore, interaction effects of diurnal cutting time and cultivar on nutritive values and in vitro gas production are still limited data available. Hence, this study was to investigate the effects of cultivar and diurnal cutting time on chemical compositions, in vitro dry matter digestibility (IVDMD) and in vitro gas production parameters.

\section{MATERIALS AND METHODS}

All procedures involving animals were conducted under the regulations of UK Home Office Animals (Scientific Procedures) Act, 1986.

\section{Experimental design}

The present study was designed as a 3 (perennial ryegrass cultivars) $\times 3$ (diurnal cutting times) factorial design experiment at Plas Gogerddan, Aberystwyth, UK $\left(52^{\circ} 25^{\prime} 52.1^{\prime \prime} \mathrm{N}\right.$, $\left.4^{\circ} 01^{\prime} 01.8^{\prime \prime} \mathrm{W}\right)$. The 3 grass cultivars included a benchmark WSC perennial ryegrass cultivar 'Premium' and 2 high WSC cultivars AberAvon and AberMagic. The 9 plots for 3 cultivars (3 plots for each cultivar) were arranged in a randomized block design, and each plot was $12.5 \mathrm{~m} \times 1.2 \mathrm{~m}\left(15 \mathrm{~m}^{2}\right)$. Before the beginning of the experiment, ryegrass sward was trimmed throughout at a residual height of $4 \mathrm{~cm}$ with a Haldrup harvester, and then allowed to re-grow $3 \mathrm{wk}$ to reach the height of ca. $20 \mathrm{~cm}$ in simulation to grazing condition. Five quadrats $(0.5 \mathrm{~m} \times 0.5 \mathrm{~m})$ were taken in a "W" shape across each plot in 7th regrowth for a consecutive $3 \mathrm{~d}$ from 11 to
13 September. Diurnal cutting time was 0700 (AM, half hour after sun rise; GMT+1 in UK), 1330 (Noon, the strongest radiation), and 1900 (PM, half hour before sunset) in September, respectively. The grass samples taken from 5 quadrats in each plot in a consecutive $3 \mathrm{~d}$ at the same cutting time were pooled into one sample for each plot. Samples freezedried at $-20^{\circ} \mathrm{C}$ were ground through $1 \mathrm{~mm}$ sieve screen, and then divided into 2 subsamples. One portion was used for the measurement of in vitro gas production, and another was used for determining chemical compositions.

\section{In vitro fermentation measurement}

Fermentation systems were consisted of 30 (27 samples + 3 blanks without forage substrate) $160 \mathrm{~mL}$ air tight serum bottles (Phase Separations Ltd., Clwyd, UK). All bottles were incubated in a water bath at a constant temperature of $39^{\circ} \mathrm{C}$ and maintained in an anaerobic environment. Incubations were repeated when fermentation parameters for the same treatment deviated by more than $10 \%$ from average value.

Rumen fluid was taken from 3 fistulated cows grazed in perennial ryegrass pasture in morning. Mixed rumen fluid preserved in a pre-heated vacuum $\left(39.5^{\circ} \mathrm{C}\right)$ flask was rapidly transported into laboratory (within $1 \mathrm{~h}$ ) and then strained through a double layer of muslin. All laboratory handling of rumen fluid was carried out under a continuous flow of $\mathrm{CO}_{2}$.

Each bottle contained $95 \mathrm{~mL}$ mixture of buffer solution and rumen fluid $(2: 1, \mathrm{v} / \mathrm{v})$ and $1.0 \mathrm{~g}$ ground dry forage substrates, except for 3 blank bottles with no forage substrate added. The buffer solution was formulated by Menke and Steingass [16]. A mixture of rumen fluid, buffer solution and ground forage substrates was maintained under an anaerobic environment. Pressure and volume for gas production in each bottle were recorded at $2,5,8,11,14,17,22,28,36$, and $48 \mathrm{~h}$, as well as sampling gas, respectively. Gas sample was collected using a plastic gas collection bag attached to serum bottle through a 3-way syringe valve, and finished while reading of pressure transducer is zero (ambient pressure). Bottles were stored at $4^{\circ} \mathrm{C}$ in the end of fermentation. For determination of DM loss, the residues in the bottle were vacuumfiltered through a weighed glass microfiber filter $(1.6 \mu \mathrm{m})$ on a porcelain funnel and rinsed twice with distilled water (100 $\mathrm{mL}$ ), and then placed into a grip-seal bag for DM content measured.

\section{Chemical analysis}

The DM content was determined by freeze-dried at $-20^{\circ} \mathrm{C}$. Ash content was analyzed by combusting the ground samples at $550^{\circ} \mathrm{C}$ for $6 \mathrm{~h}$ on a muffle. Nitrogen content was analyzed by micro-Kjeldahl techniques using 'Kjeltec' apparatus (Perstorp Analytical Ltd., Maidenhead, Berkshire, UK). Neutral detergent fiber (NDF) concentration without alpha-amylase and sodium sulfite, expressed as inclusive of residual ash, was 
determined according to the method of Van Soest and Wine [17] using the Tecator Fibretec System equipment (Tecator Ltd., Thornbury, Somerset, UK). The WSC content was determined as described by Thomas [18]. Methane and carbon dioxide concentrations sampled from incubation vessels were analyzed by Infrared gas analysis (5000 series gas analyzer; Analytical Development Co. Ltd., Hoddesdon, Hertfordshire, UK).

\section{Statistical analysis}

The analysis was carried out in SAS (version 9.2, SAS Institute Inc., Cary, NC, USA) with a probability level of 0.05 for significance of treatments and interaction. Generalize linear model procedure was used to evaluate the effects of cultivar and cutting time on nutrient values and gas production parameters with cutting time and cultivar as fixed factor, and Pearson Correlation procedure was implemented to describe the relationships between IVDMD and in vitro gas production parameters and linear and quadratic chemical compositions. Figures were made by Origin 2017 using the linear and binomial fitting and/or exponential fitting (OriginLab Corporation, Northampton, MA, USA).

The Gompertz function (Eq.1, [19]) was used to analyze total gas and $\mathrm{CH}_{4}$ production using the non-linier regression analysis program (NLREG), where $\mathrm{GP}_{\mathrm{t}}$ is cumulative gas production $(\mathrm{mL} / \mathrm{g} \mathrm{DM}), \mathrm{A}$ is the theoretical maximum of gas production $(\mathrm{mL}), \mathrm{b}$ is the rate of gas production $(\mathrm{mL} / \mathrm{h})$, lag is lag time $(\mathrm{h}), \mathrm{t}$ is the incubation time $(\mathrm{h})$ and $\mathrm{e}$ is the constant. Mean prediction error (MPE, Eq.2) was used to describe the prediction precision [2], where $\mathrm{M}$ and $\mathrm{P}$ are the actual measured and predicted values, respectively, and $\mathrm{n}$ is the number of pair of values of $\mathrm{P}$ compared with $\mathrm{M}$.

$$
\begin{aligned}
& \mathrm{GP}_{\mathrm{t}}=\mathrm{A} \times \exp \left\{-\exp \left[1+\frac{\mathrm{b} \times \mathrm{e}}{\mathrm{A}}(\operatorname{lag}-\mathrm{t})\right]\right\} \\
& \mathrm{MPE}=\sqrt{\frac{\sum(\mathrm{P}-\mathrm{M})^{2}}{\mathrm{n}}} /\left(\sum \mathrm{M} / \mathrm{n}\right)
\end{aligned}
$$

\section{RESULTS}

Effect of cutting time and cultivar on chemical compositions and in vitro dry matter digestibility Neither cutting time nor cultivar affected organic matter (OM) content. The NDF content for grass cut in PM was lower $(\mathrm{p}<0.001)$ than that cut in AM, but the effect of cutting time depended on the cultivars such as the NDF content for AberAvon cut in PM was no significant difference with that for grass cut in AM ( $p>0.05)$. Both cutting time and cultivar had significant effects on N and WSC concentrations ( $\mathrm{p}<$ 0.001). The WSC concentrations were increased when the cutting time was moved from AM to Noon and then to PM $(\mathrm{p}<0.001)$, but $\mathrm{N}$ concentrations were decreased $(\mathrm{p}<0.001)$. As expected, high WSC cultivars contained higher WSC concentration ( $p<0.001)$. Nitrogen concentration for AberMagic cultivar was significantly lower than that for AberAvon and benchmark cultivar (Table 1).

There were only main effects of cultivar and cutting time on IVDMD. As expected, both grass cut in Noon or PM ( $\mathrm{p}<$ $0.001)$ and high WSC cultivars $(\mathrm{p}=0.043)$ had greater IVDMD than that for grass cut in AM and/or benchmark cultivar. There was no significantly different in IVDMD for grass cut in Noon and PM (Table 1).

\section{Gas production and parameters of Kinetics function} Kinetics function for gas production: Gas production for the 3 cultivars rapidly increased from 2 to $17 \mathrm{~h}$, the increment was faded down from 22 to $36 \mathrm{~h}$ and then the curves tended to be stable (Figure 1). The interaction of cutting time and cultivar affected cumulative total gas production (TGP, $\mathrm{mL} / \mathrm{g}$ $\mathrm{DM})$ only at $2(\mathrm{p}<0.01)$ and $48 \mathrm{~h}(\mathrm{p}<0.05)$ for incubation, and affected $\mathrm{CH}_{4}$ production $(\mathrm{mL} / \mathrm{g}$ DM) only at $2 \mathrm{~h}(\mathrm{p}<0.001)$. Cutting time and cultivar both had significant effects on TGP from 2 to $48 \mathrm{~h}$, except cultivar no affecting TGP at $2 \mathrm{~h}$. The TGP and $\mathrm{CH}_{4}$ production for grass cut in Noon and $\mathrm{PM}$ were higher than that cut in AM. High WSC cultivars had greater TGP, except TGP for AberAvon was no difference with that for Premium at 2, 36, and $48 \mathrm{~h}$. The $\mathrm{CH}_{4}$ production for Pre-

\begin{tabular}{|c|c|c|c|c|c|c|c|c|c|c|c|c|c|}
\hline \multirow{2}{*}{ Items } & \multicolumn{3}{|c|}{ AberAvon } & \multicolumn{3}{|c|}{ AberMagic } & \multicolumn{3}{|c|}{ Premium } & \multirow{2}{*}{ SEM } & \multicolumn{3}{|c|}{$p$-value } \\
\hline & $\mathrm{AM}$ & Noon & PM & $\mathrm{AM}$ & Noon & PM & AM & Noon & PM & & Cultivar & Cutting time & Interaction \\
\hline OM (g/kg DM) & 934 & 934 & 939 & 946 & 939 & 933 & 939 & 940 & 940 & 9.2 & 0.709 & 0.932 & 0.622 \\
\hline $\mathrm{N}$ (g/kg DM) & $39.8^{e}$ & $35.5^{\text {cd }}$ & $34.1^{b c}$ & $35.9^{d}$ & $33.4^{\mathrm{ab}}$ & $33.1^{a b}$ & $39.6^{e}$ & $36.2^{d}$ & $32.0^{\mathrm{a}}$ & 0.79 & $<0.001$ & $<0.001$ & 0.004 \\
\hline NDF (g/kg DM) & $394^{\mathrm{bc}}$ & $403^{\text {de }}$ & $398^{\text {cd }}$ & $408^{\mathrm{ef}}$ & $401^{\text {cde }}$ & $384^{a}$ & $414^{f}$ & $388^{\mathrm{ab}}$ & $398^{\text {cd }}$ & 4.0 & 0.638 & $<0.001$ & $<0.001$ \\
\hline WSC (g/kg DM) & $142^{b}$ & $180^{\text {de }}$ & $196^{f}$ & $162^{c}$ & $199^{f}$ & $217^{9}$ & $112^{\mathrm{a}}$ & $174^{d}$ & $186^{\mathrm{e}}$ & 4.6 & $<0.001$ & $<0.001$ & 0.007 \\
\hline IVDMD (g/kg DM) & $817^{\mathrm{bc}}$ & $830^{\text {cd }}$ & $825^{\mathrm{bcd}}$ & $809^{a b}$ & $828^{\text {cd }}$ & $835^{d}$ & $794^{a}$ & $829^{\text {cd }}$ & $815^{b c}$ & 8.2 & 0.043 & $<0.001$ & 0.226 \\
\hline
\end{tabular}

Table 1. Effects of cutting time and cultivar on chemical compositions and IVDMD $(n=27)$

IVDMD, in vitro dry matter digestibility; SEM, standard error of the mean; OM, organic matter; DM, dry matter; N, nitrogen; NDF, neutral detergent fiber; WSC, water soluble carbohydrates.

${ }^{a-9}$ Means within the same row with same letters are not significantly different $(p>0.05)$. 

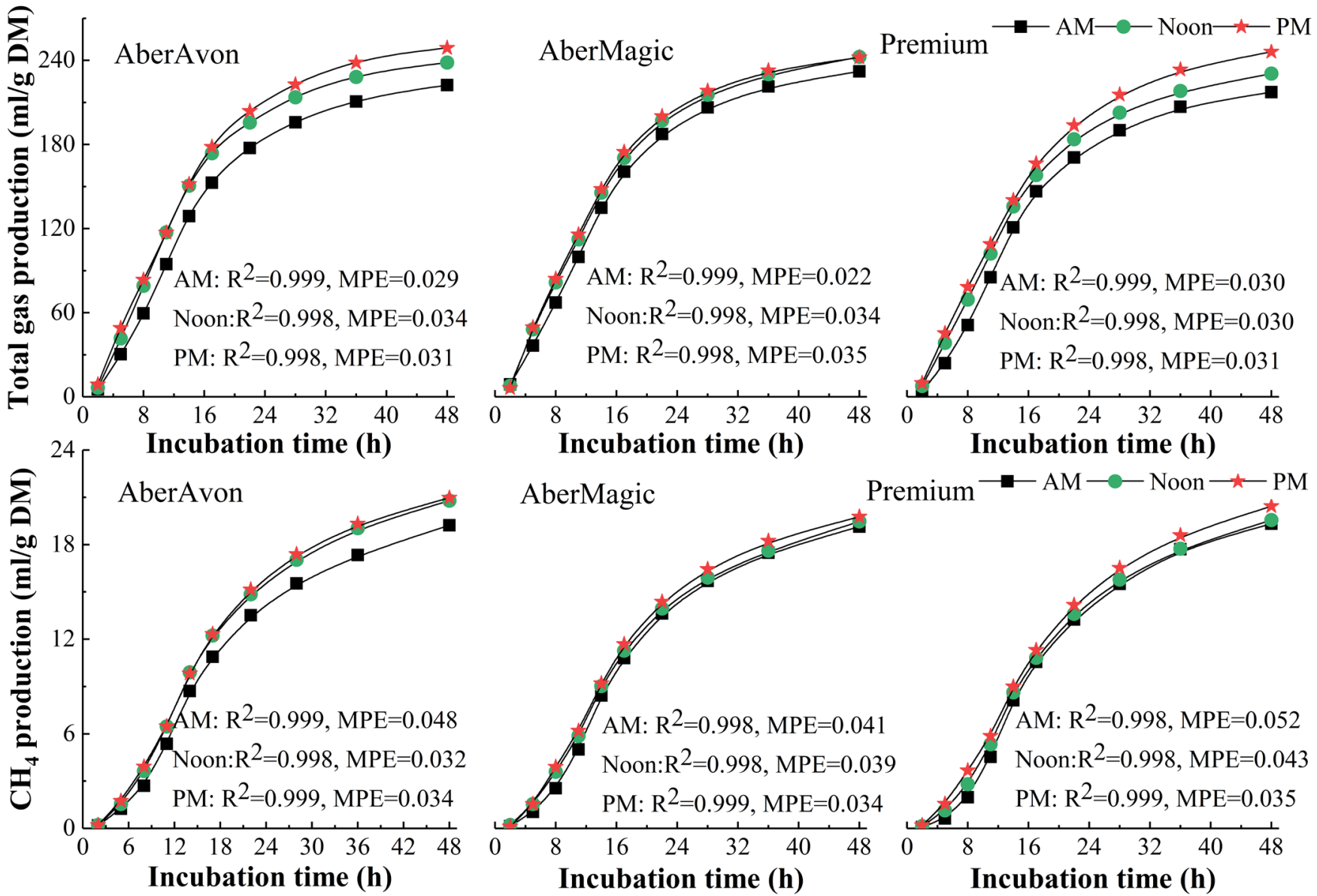

Figure 1. Cumulative total gas and $\mathrm{CH}_{4}$ production at various incubation times of 3 cultivars. MPE, mean prediction error; $\mathrm{R}^{2}$, the pseudo correlation coefficient.

mium was numerically higher than that of AberMagic at all incubation time, and lower than that of AberAvon at 2 to 22, and $48 \mathrm{~h}$. Methane production for grass cut in PM was greater than that cut in $\mathrm{AM}(\mathrm{p}<0.05)$.

Effects of cutting time and cultivar on in vitro gas production parameters: Either cultivar or cutting time had significant effects on TGP parameters, except TGP/in vitro digestible DM incubated. Grass cut in Noon and PM had greater TGP, expressed as a proportion of $\mathrm{DM}, \mathrm{OM}$, and in vitro digestible DM incubated, $A$ and $b$, and lag time was decreased (Table 2). High WSC cultivars had higher TGP parameters and b, and lower lag time, and all parameters for AberMagic cut in Noon and PM were no significantly different.

There were no interaction effects on $\mathrm{CH}_{4}$ production parameters, except lag time, and b was not affected by both factors (Table 2). Methane yield per unit of DM and OM incubated, and A for high WSC cultivars were slightly higher than that for benchmark cultivar, and high WSC cultivars had lower lag time. Grass cut in Noon and PM had higher $\mathrm{CH}_{4} / \mathrm{DM}$ incubated, $\mathrm{CH}_{4} / \mathrm{OM}$ incubated, and $\mathrm{A}$. However, the effect of cutting time was determined by cultivar, such as AberAvon cut in Noon and PM contained higher $\mathrm{CH}_{4}$ production than that cut in $\mathrm{AM}$, but that for AberMagic was not affected by cutting time.

Relationships between chemical compositions and parameters for gas production: The correlation coefficients derived from linear parameters were not lower than that from quadratic parameters, except $\mathrm{N}$ and NDF concentrations (Figure 2). The IVDMD was negatively related to OM, N, and NDF concentrations, and positively related to WSC, WSC/N, and WSC/ NDF concentrations.

The relationships between nutrient composition parameters and in vitro fermentation parameters had higher correlation coefficients when the linear regression was fitted as linear, rather than as quadratic (not presented), except N, NDF, and $\mathrm{NDF} / \mathrm{OM}$ concentrations. Neither $\mathrm{CH}_{4} /$ in vitro digestible DM incubated nor $\mathrm{b}$ for $\mathrm{CH}_{4}$ production was correlated with any chemical composition parameter (Table 3). The TGP/DM incubated, $\mathrm{CH}_{4} / \mathrm{DM}$ incubated, $\mathrm{A}$, and $\mathrm{b}$ of TGP, and $\mathrm{A}$ of $\mathrm{CH}_{4}$ production were all positively related to WSC, WSC/N, and WSC/NDF contents, and negatively related to $\mathrm{N}$ content. Meanwhile, lag time for TGP and $\mathrm{CH}_{4}$ was negatively related 
Table 2. Effects of cutting time and cultivar on in vitro fermentation parameters $(n=27)$

\begin{tabular}{|c|c|c|c|c|c|c|c|c|c|c|c|c|c|}
\hline \multirow{2}{*}{ Items } & \multicolumn{3}{|c|}{ AberAvon } & \multicolumn{3}{|c|}{ AberMagic } & \multicolumn{3}{|c|}{ Premium } & \multirow{2}{*}{ SEM } & \multicolumn{3}{|c|}{$\mathrm{p}$-value } \\
\hline & $\mathrm{AM}$ & Noon & PM & AM & Noon & PM & $\mathrm{AM}$ & Noon & PM & & Cultivar & Cutting time & Interaction \\
\hline \multicolumn{14}{|l|}{ TGP } \\
\hline TGP/DM incubated (mL/g DM) & $222^{\mathrm{ab}}$ & $239^{\text {cd }}$ & $249^{e}$ & $232^{c}$ & $243^{\text {de }}$ & $242^{\mathrm{de}}$ & $217^{\mathrm{a}}$ & $231^{b c}$ & $246^{\text {de }}$ & 4.2 & 0.017 & $<0.001$ & 0.033 \\
\hline TGP/OM incubated $(\mathrm{mL} / \mathrm{g})$ & $238^{\mathrm{ab}}$ & $256^{d}$ & $265^{d}$ & $245^{\mathrm{bc}}$ & $258^{d}$ & $260^{d}$ & $232^{\mathrm{a}}$ & $245^{b c}$ & $265^{d}$ & 5.2 & 0.032 & $<0.001$ & 0.205 \\
\hline TGP/in vitro digestible DM incubated $(\mathrm{mL} / \mathrm{g})$ & $272^{\mathrm{a}}$ & $287^{\text {bc }}$ & $302^{d}$ & $287^{\mathrm{bc}}$ & $293^{c d}$ & $290^{\text {bcd }}$ & $274^{a}$ & $278^{\mathrm{ab}}$ & $302^{d}$ & 5.8 & 0.301 & $<0.001$ & 0.012 \\
\hline $\mathrm{A}(\mathrm{mL} / \mathrm{g} \mathrm{DM})$ & $217^{a b}$ & $231^{\text {cd }}$ & $243^{e}$ & $228^{\text {cd }}$ & $236^{\text {de }}$ & $237^{\text {de }}$ & $212^{a}$ & $225^{b c}$ & $241^{e}$ & 2.1 & 0.022 & $<0.001$ & 0.029 \\
\hline$b(\mathrm{~mL} / \mathrm{h})$ & $11.5^{\mathrm{a}}$ & $13.0^{c}$ & $12.7^{\mathrm{bc}}$ & $11.6^{\mathrm{a}}$ & $12.1^{a b}$ & $12.5^{b c}$ & $11.3^{\mathrm{a}}$ & $11.4^{\mathrm{a}}$ & $11.5^{\mathrm{a}}$ & 0.14 & 0.001 & 0.006 & 0.152 \\
\hline Lag time (h) & $2.89^{d}$ & $2.13^{b c}$ & $1.75^{\mathrm{ab}}$ & $2.36^{c}$ & $1.66^{\mathrm{a}}$ & $1.72^{\mathrm{ab}}$ & $3.40^{e}$ & $2.11^{b c}$ & $1.63^{\mathrm{a}}$ & 0.121 & 0.004 & $<0.001$ & 0.020 \\
\hline \multicolumn{14}{|l|}{$\mathrm{CH}_{4}$} \\
\hline $\mathrm{CH}_{4} / \mathrm{DM}$ incubated $(\mathrm{mL} / \mathrm{g} \mathrm{DM})$ & $19.2^{\mathrm{a}}$ & $20.8^{b c}$ & $21.0^{c}$ & $19.1^{\mathrm{a}}$ & $19.5^{\mathrm{ab}}$ & $19.8^{\mathrm{ab}}$ & $19.3^{\mathrm{a}}$ & $19.6^{\mathrm{ab}}$ & $20.4^{\mathrm{abc}}$ & 0.63 & 0.078 & 0.016 & 0.516 \\
\hline $\mathrm{CH}_{4} / \mathrm{OM}$ incubated $(\mathrm{mL} / \mathrm{g})$ & $20.6^{\mathrm{ab}}$ & $22.3^{c}$ & $22.3^{c}$ & $20.2^{\mathrm{a}}$ & $20.7^{\mathrm{ab}}$ & $21.2^{\mathrm{abc}}$ & $20.6^{\mathrm{ab}}$ & $20.8^{\mathrm{ab}}$ & $21.7^{\mathrm{bc}}$ & 0.69 & 0.059 & 0.016 & 0.616 \\
\hline $\mathrm{CH}_{4}$ /in vitro digestible $\mathrm{DM}$ incubated $(\mathrm{mL} / \mathrm{g})$ & $23.5^{\mathrm{a}}$ & $25.0^{a b}$ & $25.4^{b}$ & $23.7^{\mathrm{a}}$ & $23.5^{\mathrm{a}}$ & $23.7^{\mathrm{a}}$ & $24.3^{\mathrm{ab}}$ & $23.6^{\mathrm{a}}$ & $25.1^{\mathrm{ab}}$ & 0.82 & 0.102 & 0.173 & 0.281 \\
\hline $\mathrm{A}(\mathrm{mL} / \mathrm{g} \mathrm{DM})$ & $18.7^{\mathrm{a}}$ & $20.3^{b c}$ & $20.6^{c}$ & $18.7^{\mathrm{a}}$ & $19.0^{\mathrm{a}}$ & $19.4^{\mathrm{abc}}$ & $18.9^{\mathrm{a}}$ & $19.1^{\mathrm{ab}}$ & $20.2^{\mathrm{bc}}$ & 0.18 & 0.067 & 0.003 & 0.396 \\
\hline $\mathrm{b}(\mathrm{mL} / \mathrm{h})$ & 0.875 & 0.944 & 0.941 & 0.900 & 0.861 & 0.893 & 0.908 & 0.869 & 0.860 & 0.0388 & 0.393 & 0.978 & 0.514 \\
\hline Lag time (h) & $4.77^{b}$ & $4.16^{a}$ & $4.00^{a}$ & $5.24^{b}$ & $4.05^{\mathrm{a}}$ & $3.99^{\mathrm{a}}$ & $5.82^{c}$ & $4.77^{b}$ & $4.05^{\mathrm{a}}$ & 0.131 & 0.002 & $<0.001$ & 0.081 \\
\hline
\end{tabular}

SEM, standard error of the mean; TGP, total gas production; DM, dry matter; OM, organic matter; $A$, theoretical maximum of gas production; $b$, the rate of gas production.

a-e Means within the same row with same letters are not significantly different $(p>0.05)$.

to WSC, WSC/N, WSC/NDF, and IVDMD, and positively related to N, NDF, and NDF/OM contents. The IVDMD had positive effect on TGP parameters, but had no effect on $\mathrm{CH}_{4}$ yield.

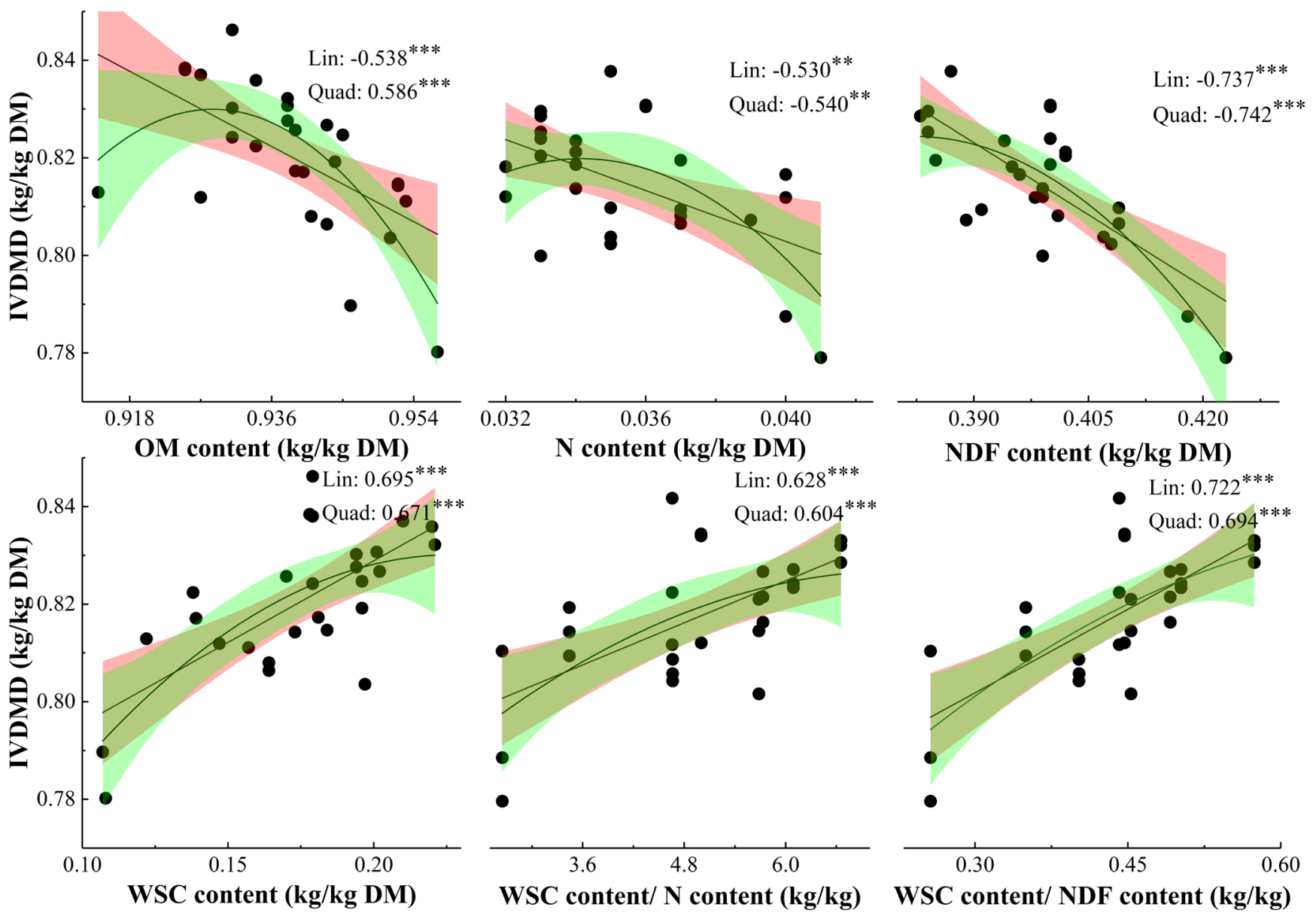

Figure 2. Relationship between chemical compositions and IVDMD for ryegrass. Lin, linear; Quad, quadratic. ${ }^{*} p<0.05,{ }^{* *} p<0.01,{ }^{* * *} p<0.001$. Values represents Pearson correlation coefficient. IVDMD, in vitro dry matter digestibility; OM, organic matter; N, nitrogen; NDF, neutral detergent fiber; WSC, water soluble carbohydrates. The fitting lines represent linear and quadratic fits, and the shadows represent the range of $95 \%$ confidence interval. 
Table 3. Relationship between nutrition composition and in vitro DM digestibility, and gas production parameters ( $\mathrm{n}=27$ )

\begin{tabular}{|c|c|c|c|c|c|c|c|c|}
\hline Items & $\begin{array}{c}\text { OM } \\
\text { (g/kg DM) }\end{array}$ & $\begin{array}{c}N \\
(g / k g ~ D M)\end{array}$ & $\begin{array}{c}\text { NDF } \\
\text { (g/kg DM) }\end{array}$ & $\begin{array}{c}\text { WSC } \\
\text { (g/kg DM) }\end{array}$ & $\begin{array}{l}\text { WSC/N } \\
(\mathrm{kg} / \mathrm{kg})\end{array}$ & $\begin{array}{c}\text { WSC/NDF } \\
(\mathrm{kg} / \mathrm{kg})\end{array}$ & $\begin{array}{c}\text { NDF/OM } \\
(\mathrm{kg} / \mathrm{kg})\end{array}$ & $\begin{array}{l}\text { IVDMD } \\
\text { (g/kg DM) }\end{array}$ \\
\hline \multicolumn{9}{|l|}{ TGP } \\
\hline TGP/OM incubated $(\mathrm{mL} / \mathrm{g})$ & - & $-0.853^{* * *}$ & $-0.400^{*}$ & $0.817^{* * *}$ & $0.836^{* * *}$ & $0.791^{* * *}$ & $-0.354^{*}$ & $0.604^{* * *}$ \\
\hline TGP/in vitro digestible DM incubated $(\mathrm{mL} / \mathrm{g})$ & - & $-0.733^{* * *}$ & - & $0.640 * * *$ & $0.700 * * *$ & $0.594^{* * *}$ & - & - \\
\hline $\mathrm{A}(\mathrm{mL} / \mathrm{g} D M)$ & - & $-0.846^{* * *}$ & - & $0.808 * * *$ & $0.845^{* * *}$ & $0.779 * * *$ & $-0.344^{*}$ & $0.463^{* *}$ \\
\hline \multicolumn{9}{|c|}{ 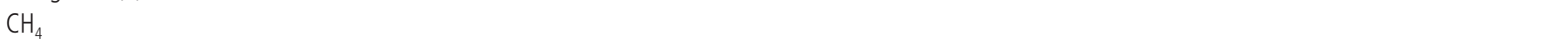 } \\
\hline $\mathrm{CH}_{4} / \mathrm{DM}$ incubated (mL/g DM) & - & $-0.390^{*}$ & - & $0.352^{*}$ & $0.326^{*}$ & - & - & - \\
\hline $\mathrm{CH}_{4} / \mathrm{OM}$ incubated $(\mathrm{mL} / \mathrm{g})$ & - & $-0.408^{*}$ & - & $0.352^{*}$ & - & - & - & $0.331^{*}$ \\
\hline $\mathrm{CH}_{4} /$ in vitro digestible DM incubated $(\mathrm{mL} / \mathrm{g})$ & - & - & - & - & - & - & - & - \\
\hline $\mathrm{A}(\mathrm{mL} / \mathrm{g} \mathrm{DM})$ & - & $-0.460^{*}$ & - & $0.396^{*}$ & $0.378^{*}$ & $0.353^{*}$ & - & - \\
\hline
\end{tabular}

DM, dry matter; OM, organic matter; N, nitrogen; NDF, neutral detergent fiber; WSC, water soluble carbohydrates; IVDMD, in vitro dry matter digestibility; TGP, total gas production; $A$, theoretical maximum of gas production; $b$, the rate of gas production.

- represents no significant relationship. ${ }^{*} p \leq 0.05,{ }^{* *} p \leq 0.01,{ }^{* * *} p \leq 0.001$.

\section{DISCUSSION}

\section{Effects on cutting time and cultivar on chemical compositions}

The relative changes in WSC concentration also can be achieved either through improved cultivars and genetic selection or cutting management. With PM cutting, the WSC concentration of ryegrass was increased by up to $61 \mathrm{~g} / \mathrm{kg} \mathrm{DM}$ in present study, while genetic selection resulted in an increase up to $35 \mathrm{~g} / \mathrm{kg}$ DM comparing with the benchmark cultivar. The WSC concentration in the present study harvested in middle of September were, on average, 173, 193, and 157 $\mathrm{g} / \mathrm{kg}$ DM for AberAvon, AberMagic, and Premium, respectively, which were far lower than that $(307,302$, and $269 \mathrm{~g} / \mathrm{kg}$ $\mathrm{DM}$, separately) for the same 3 cultivars harvested in late May and early June conducted in the same region [20]. The gap could be leaded by that grass utilized in September contains lower proportion of sheaths and higher proportion of stems, compared with that utilized in May [10], and also could be attributed to lower solar radiation and the air temperature in September [21]. When photosynthesis production in herbage exceeds carbohydrates utilization, WSC would be accumulated during the day $[15,22]$, which was in line with that soluble carbohydrate content in Festuca was accumulated up until 1800 [23] and WSC concentration for alfalfa cut in PM was higher than that cut in AM [3]. The WSC contents for 3 cultivars were considerably increased from AM to Noon, while the rate of increment was slowly from Noon to PM, which might be due to lower net photosynthetic rate of ryegrass in PM than that in AM [22].

Other chemical composition concentrations probably varied in a passive manner among different cutting time by concentrations (e.g. OM) or dilutions (e.g. crude protein [CP] and NDF) effects within the accumulation of nonstructural carbohydrates $[15,23,24]$. There was a decrease of NDF concentration for AberMagic and Premium cut in Noon and PM, which was consistent with the studies of Lechtenberg et al [23], Ellis et al [12], and Smit and Elgersma [14]. In the absence of photosynthesis, total soluble carbohydrate content falls due to respiration during the night, which leads to an increase in protein synthesis [15]. The previous studies also reported consistent results, for example, ca. $50 \%$ of daily increment of sucrose was lost from sundown to the early morning of the 2400 and $63 \%$ of leaf starch increased between 6 am and $6 \mathrm{pm}$ was lost between the early morning of the 2400 and 0300 [23]. The peak of CP concentration for alfalfa showed between 0300 and 0600 , which gradually declined after sunrise [24]. The present study obtained a negative relationship between N and WSC content (Pearson correlation coefficient was $-0.819, \mathrm{p}<0.001$ ), and grass cut in Noon and PM and high WSC cultivars contained higher WSC/N content. Hence, in present study, grass cut in Noon and PM cultivars contained greater WSC and lower N concentrations.

\section{In vitro dry matter digestibility}

In current study, IVDMD for grass cut in Noon and PM was higher than that cut in AM, which was in line with the results of Burner and Belesky [25], and Alende [26]. The IVDMD for Noon and PM samples of ryegrass were $2.78 \%$ and $2.28 \%$ higher than AM samples, which was higher than an increase of $1.6 \%$ for alfalfa samples cut from 6 am to $6 \mathrm{pm}$ [23]. Mean- 
while, IVDMD for high WSC cultivars was greater than that for Premium, which was due to that microbial protein synthesis would be compensated by a decrease in dietary $\mathrm{N}$ supply, especially when rapidly and sufficiently available energy was used as the energy source [27]. As it was evidenced by that the decrease in ratio of $\mathrm{N}$ to soluble sugar improved the $\mathrm{N}$ utilization and milk yield [8], and the slightly higher ruminal $\mathrm{pH}$ for cows offered alfalfa cut in PM due to lower acetate concentration leaded to numerical greater DM digestibility than offered alfalfa cut in AM [3]. As showed in Figure 2, WSC/N and WSC/NDF all had positive relationships with IVDMD, which was agreed that NDF content had negative relationship with digestibility $[2,28]$, and WSC content was positively correlated to DM digestibility [2]. Hence, both grass utilized in Noon and PM and high WSC cultivars have the potential to improve IVDMD.

In the present study, $\mathrm{N}$ content negatively related to IVDMD was not in line with the study of Stergiadis et al [2], which might be attributed to relatively higher $\mathrm{N}$ concentration ranging from 31.5 to $40.9 \mathrm{~g} / \mathrm{kg}$ DM (197 to $256 \mathrm{~g} / \mathrm{kg}$ DM for CP concentration) in present study. When the $\mathrm{N}$ concentration was $34.0 \mathrm{~g} / \mathrm{kg} \mathrm{DM}$, the value of IVDMD predicted by $\mathrm{N}$ concentration reached the peak value in present study. The threshold value was close to $35 \mathrm{~g} / \mathrm{kg}$ DM reported by Stergiadis et al [2], which was exhibited that increasing grass $\mathrm{N}$ content improved $\mathrm{N}$ digestibility when grass $\mathrm{N}$ content was below about $35 \mathrm{~g} / \mathrm{kg} \mathrm{DM}$ and any increase in grass $\mathrm{N}$ content over $35 \mathrm{~kg} / \mathrm{kg}$ would decrease $\mathrm{N}$ digestibility. In present study, the response of IVDMD to $\mathrm{N}$ content shifted from no correlative to negative, after $\mathrm{N}$ content increased from below to beyond $34.0 \mathrm{~g} / \mathrm{kg} \mathrm{DM}$, which could be explained by that nitrogen exceeding the $\mathrm{N}$ requirement for rumen microbial activities would produce excessive ammonia in vitro, and result in high $\mathrm{N}$ excretion especially in urine in vivo [11]. Hence, diet based on high WSC cultivars and grass cut in Noon and PM containing rich rapid available soluble sugar, and high solubility and degradability of fresh-grass $\mathrm{N}$ [10], where $\mathrm{N}$ content mainly was replaced by WSC content, could offer optimum $\mathrm{N}$ and energy for ruminant production, and have the potential to improve DM digestibility and reduce $\mathrm{N}$ excretion.

\section{Parameters of gas production}

The present results showed that TGP was affected both cultivar and cutting time, and $\mathrm{CH}_{4}$ production was only affected by cutting time, which were in line with the results of Tang et al [29]. In the present study, all growth rates of gas production were firstly increased and then declined, which might be caused by the decrease of fermented OM and protein availability, and accumulation of volatile fatty acids (VFAs) during the process of fermentation. The TGP rapidly increased from 2 to $17 \mathrm{~h}$, and $\mathrm{CH}_{4}$ production increased from 5 to $22 \mathrm{~h}$ of
$48 \mathrm{~h}$ incubation, which were consistent with those reported by Lovett et al [30], but Tang et al [29] showed that relatively rapid fermentation rate was presented after $8 \mathrm{~h}$ for $48 \mathrm{~h}$ incubation. In present study, $52 \%$ to $65 \%$ of gas production occurred at the first $14 \mathrm{~h}$ and $54 \%$ to $59 \%$ of $\mathrm{CH}_{4}$ occurred at first $17 \mathrm{~h}$, which had obviously lower fermentation rates than that from the study of Muck et al [31] that 56\% to $70 \%$ of gas production occurred at $9 \mathrm{~h}$ for the $96 \mathrm{~h}$ incubation. A range of factors affect the fermentation rate, e.g., species of donor animals, diets fed to donor animals and nutritive values of fermentation substrates [32].

In the present study, high sugar cultivars contained greater WSC content, thus had faster fermentation rate (Tables 2 and 3), e.g., higher fermentation rates during the first couple of hours and lower lag time of gas production. However, the absence of WSC content affecting $\mathrm{CH}_{4}$ yield might be contributed by unexpected lower difference in WSC concentration of 3 cultivars, which was in line with the studies of Niderkorn et al [20] and Smit and Elgersma [11]. Meanwhile, Ellis et al [12] reported sugars might have a higher methanogenic potential than starch or even fiber, and lead to higher $\mathrm{CH}_{4}$ yield in vivo ( $\mathrm{kg} / \mathrm{kg} \mathrm{DM}$ intake). By contrast, Lovett et al [30] and Kim et al [7] found that compared to low WSC cultivars, diet based on high WSC cultivars reduced $\mathrm{CH}_{4}$ yield, as a proportion of feed intake. In present study, either grass cut in noon and PM or high WSC cultivars was not effective way to lower $\mathrm{CH}_{4}$ yield. However, emission intensity in terms of products (e.g. weight gain and milk yield) would be potential to be lower [7], due to higher total and digestible DM yield per ha would be expected to result in growing faster and shorten cycle of slaughter.

The present study found that IVDMD, WSC, WSC/N, and WSC/NDF concentrations had positive relationships with TGP expressed as per $\mathrm{g}$ DM incubated, and $\mathrm{A}$ and $\mathrm{b}$ for TGP, but those were negative with the lag time for TGP, which was in line with the study of Tang et al [29]. The result implied that the high soluble carbohydrates was beneficial for rumen fermentation, and high $\mathrm{N}$ content without sufficient utilized energy leading to excess the requirement of microbial synthesis resulted in lower TGP due to excessive ammonia which has negative effect on TGP. The positive relationship between $\mathrm{CH}_{4}$ production and WSC content was in line with Ellis et al [12]. The NDF content was the most effective diet factor to reduce the rate of rumen fermentation, and $\mathrm{NDF} / \mathrm{OM}$ was positively related to the ratio of acetate/VFAs and negatively related to the ratio of propionate/VFAs [28]. In the present study, grass NDF content had a negative relationship with TGP, but $\mathrm{CH}_{4}$ yield not affected by NDF content might be attributed to not large enough difference among NDF concentrations of all samples. The results imply that both increasing WSC content and improving DM digestibility are beneficial for rumen fermentation and the rumen microbial population 
[9,30]. Meanwhile, the synchronous supply of $\mathrm{N}$ and fermentable energy to the rumen is essential to maximize the microbial growth and consequently $\mathrm{N}$ utilization efficiency [33]. Hence, further studies are needed to quantity the interaction effect of $\mathrm{N}$ and WSC concentrations on gas production, especially the effect of WSC content on $\mathrm{CH}_{4}$ yield in vivo.

The relationships between gas production parameters and chemical compositions were different under different $\mathrm{N}$ level (Table 4). After $\mathrm{N}$ content changing from below to beyond $34.0 \mathrm{~g} / \mathrm{kg} \mathrm{DM}$, the effect of $\mathrm{N}$ content on TGP yield was changed from no correlative to negative, and the respond of TGP yield to WSC content was changed from negative to positive. The results probably could be explained by that the high available fermented energy exceeding the requirement of microbial synthesis would contribute to lower $\mathrm{pH}$, which is disadvantage to microorganism activity, when $\mathrm{N}$ content below $34.0 \mathrm{~g} / \mathrm{kg}$ DM. Otherwise, the insufficient WSC could not offer enough fermentable energy for meeting the requirement for microbial activity, and excessive fermentable $\mathrm{N}$ would produce excessive ammonia while $\mathrm{N}$ content beyond $34.0 \mathrm{~g} / \mathrm{kg}$ DM. In an in vivo experiment, it was reported that after $\mathrm{N}$ content reaching to $33.6 \mathrm{~g} / \mathrm{kg} \mathrm{DM}$ [34], an increase of $\mathrm{N}$ concentration had no effect on milk production and increase urinary $\mathrm{N}$ excretion for cows, and even the dietary $\mathrm{N}$ content could be decreased to ca. $24 \mathrm{~g} / \mathrm{kg}$ DM without compromising milk protein $\mathrm{N}$ yields [35]. The difference probably attributes to the no passage out rate for this in vitro experiment, which leads to the accumulation of fermentation. The further studies are required for identifying the optimal proportion of WSC and N concentrations for maximizing entire tract nutrient digestibility and $\mathrm{CH}_{4}$ emission for ruminant production.

Table 4. Correlation coefficients between nutrition composition and in vitro DM digestibility and gas production parameters with different $\mathrm{N}$ levels ( $\mathrm{N}$ content $\leq[\mathrm{n}=15]$ and $>34.0[\mathrm{n}=12] \mathrm{g} / \mathrm{kg} \mathrm{DM})$

\begin{tabular}{|c|c|c|c|c|c|c|c|c|}
\hline Items & $\begin{array}{c}\text { OM } \\
\text { (g/kg DM) }\end{array}$ & $\begin{array}{c}\mathrm{N} \\
(\mathrm{g} / \mathrm{kg} \mathrm{DM})\end{array}$ & $\begin{array}{c}\text { NDF } \\
\text { (g/kg DM) }\end{array}$ & $\begin{array}{c}\text { WSC } \\
\text { (g/kg DM) }\end{array}$ & $\begin{array}{l}\text { WSC/N } \\
(\mathrm{kg} / \mathrm{kg})\end{array}$ & $\begin{array}{c}\text { WSC/NDF } \\
(\mathrm{kg} / \mathrm{kg})\end{array}$ & $\begin{array}{c}\text { NDF/OM } \\
(\mathrm{kg} / \mathrm{kg})\end{array}$ & $\begin{array}{c}\text { IVDMD } \\
\text { (g/kg DM) }\end{array}$ \\
\hline \multicolumn{9}{|l|}{$\mathrm{N}$ content $>34.0 \mathrm{~g} / \mathrm{kg} \mathrm{DM}$} \\
\hline \multicolumn{9}{|l|}{ TGP } \\
\hline TGP/DM incubated (mL/g DM) & - & $-0.789 * * *$ & - & $0.835^{* * *}$ & $0.855^{* * *}$ & $0.825^{* * *}$ & - & $0.485^{*}$ \\
\hline TGP/OM incubated $(\mathrm{mL} / \mathrm{g})$ & - & $-0.807^{* * *}$ & - & $0.825^{* * *}$ & $0.817^{* * *}$ & $0.800 * * *$ & - & $0.614^{* * *}$ \\
\hline TGP/in vitro digestible DM incubated $(\mathrm{mL} / \mathrm{g})$ & & $-0.643^{* * *}$ & - & $0.636^{* * *}$ & $0.705^{* * *}$ & $0.628^{* * *}$ & - & - \\
\hline$A(\mathrm{~mL} / \mathrm{g} D M)$ & - & $-0.785^{* * *}$ & - & $0.812^{* * *}$ & $0.842^{* * *}$ & $0.801 * * *$ & - & $0.458 * *$ \\
\hline $\mathrm{b}(\mathrm{mL} / \mathrm{h})$ & - & $-0.528^{*}$ & - & $0.559 * *$ & $0.542^{* *}$ & $0.534 * * *$ & - & - \\
\hline Lag time (h) & - & $0.799 * * *$ & - & $-0.898^{* * *}$ & $-0.900 * * *$ & $-0.905^{* * *}$ & $0.459 * *$ & $-0.574^{* *}$ \\
\hline \multicolumn{9}{|l|}{$\mathrm{CH}_{4}$} \\
\hline $\mathrm{CH}_{4} / \mathrm{DM}$ incubated (mL/g DM) & - & - & - & $0.423^{*}$ & - & - & - & - \\
\hline $\mathrm{CH}_{4} / \mathrm{OM}$ incubated $(\mathrm{mL} / \mathrm{g})$ & - & - & - & $0.410^{*}$ & - & - & - & - \\
\hline $\mathrm{CH}_{4}$ lin vitro digestible DM incubated $(\mathrm{mL} / \mathrm{g})$ & - & - & - & - & - & - & - & - \\
\hline $\mathrm{A}(\mathrm{mL} / \mathrm{g} \mathrm{DM})$ & - & $-0.423^{*}$ & - & $0.459^{*}$ & - & $0.419^{*}$ & - & - \\
\hline $\mathrm{b}(\mathrm{mL} / \mathrm{h})$ & - & - & - & - & - & - & - & - \\
\hline Lag time $(h)$ & - & $0.558^{* *}$ & - & $-0.795^{* * *}$ & $-0.735^{* * *}$ & $-0.800 * * *$ & $0.443^{*}$ & $-0.506^{*}$ \\
\hline \multicolumn{9}{|l|}{$N$ content $\leq 34.0 \mathrm{~g} / \mathrm{kg} \mathrm{DM}$} \\
\hline \multicolumn{9}{|l|}{ TGP } \\
\hline TGP/DM incubated (mL/g DM) & - & - & - & $-0.690^{*}$ & $-0.737^{*}$ & $-0.625^{*}$ & - & - \\
\hline TGP/OM incubated $(\mathrm{mL} / \mathrm{g})$ & - & - & - & - & - & - & - & - \\
\hline TGP/in vitro digestible DM incubated $(\mathrm{mL} / \mathrm{g})$ & & & - & $-0.726^{*}$ & $-0.863^{* *}$ & $-0.838^{* *}$ & - & $-0.861^{* *}$ \\
\hline $\mathrm{A}(\mathrm{mL} / \mathrm{g} \mathrm{DM})$ & - & - & - & $-0.685^{*}$ & $-0.703^{*}$ & $-0.607^{*}$ & - & - \\
\hline $\mathrm{b}(\mathrm{mL} / \mathrm{h})$ & - & -0.801 ** & $-0.588^{*}$ & $0.646^{* *}$ & $0.650^{*}$ & $0.772^{* *}$ & - & $0.758 * *$ \\
\hline Lag time (h) & - & - & - & - & - & - & - & - \\
\hline \multicolumn{9}{|l|}{$\mathrm{CH}_{4}$} \\
\hline $\mathrm{CH}_{4} / \mathrm{DM}$ incubated (mL/g DM) & - & - & - & - & - & - & - & - \\
\hline $\mathrm{CH}_{4} / \mathrm{OM}$ incubated $(\mathrm{mL} / \mathrm{g})$ & - & - & - & - & - & - & - & - \\
\hline $\mathrm{CH}_{4}$ lin vitro digestible DM incubated $(\mathrm{mL} / \mathrm{g})$ & - & - & - & $-0.659^{*}$ & $-0.701^{*}$ & $-0.700^{*}$ & - & $-0.618^{*}$ \\
\hline $\mathrm{A}(\mathrm{mL} / \mathrm{g} \mathrm{DM})$ & - & - & - & $-0.602^{*}$ & - & - & - & - \\
\hline$b(\mathrm{~mL} / \mathrm{h})$ & - & - & - & - & - & - & - & - \\
\hline Lag time (h) & - & - & $0.477^{* *}$ & - & - & - & - & - \\
\hline
\end{tabular}

DM, dry matter; OM, organic matter; N, nitrogen; NDF, neutral detergent fiber; WSC, water soluble carbohydrates; IVDMD, in vitro dry matter digestibility; TGP, total gas production; $A$, theoretical maximum of gas production; $b$, the rate of gas production.

- represents no significant relationship; ${ }^{*} p \leq 0.05,{ }^{* *} p \leq 0.01,{ }^{* * *} p \leq 0.001$. 


\section{CONCLUSION}

Shifting AM cutting to Noon and PM cutting reduced $\mathrm{N}$ and NDF concentrations for ryegrass, and increase WSC content, IVDMD, TGP and $\mathrm{CH}_{4}$ yield, except $\mathrm{CH}_{4}$ yield for AberMagic cultivar was not significantly influenced. Compared to Premium cultivar, high WSC cultivars contained higher WSC content, IVDMD and TGP, and lower N concentration. Furthermore, AberMagic cultivar had slightly lower $\mathrm{CH}_{4}$ yield. These results reveal information and recommendations for farmers who engage in ruminants raising under zero-grazing to try to improve the cultivation of better varieties such as the high sugar varieties and/or to harvest grass at suitable time like during the mid-day, noon and/or afternoon to optimize grazing management, which would consequently increase DM digestibility by providing the optimum available WSC and $\mathrm{N}$. The AberMagic cultivar also have the potential to reduce $\mathrm{CH}_{4}$ emission, but further study for the effect on animal production in conjunction with methane emission is necessary.

\section{CONFLICT OF INTEREST}

We certify that there is no conflict of interest with any financial organization regarding the material discussed in the manuscript.

\section{ACKNOWLEDGMENTS}

The authors thank C.J. Newbold for the assistance with skilled technology and sample analysis, R. Fychan for the Plot manager and consultant, R. Sanderson and M.S. Dhanoa for statistical consultant and colleagues in Institute of Biological and Environmental Research, Aberystwyth University, Gogerddan Campus, Aberystwyth, UK. This research was supported by the Strategic Priority Research Program of Chinese Academy of Sciences (XDA2010010203), the Special Fund for AgroScientific Research in the Public Interest (20140307106), and Program for Changjiang Scholars and Innovative Research Team in University (IRT_17R250).

\section{REFERENCES}

1. Smit HJ, Tas BM, Taweel HZ, Tamminga S, Elgersma A. Effects of perennial ryegrass (Lolium perenne L.) cultivars on herbage production, nutritional quality and herbage intake of grazing dairy cows. Grass Forage Sci 2005;60:297-309. https://doi. org/10.1111/j.1365-2494.2005.00480.x

2. Stergiadis S, Allen M, Chen XJ, Wills D, Yan T. Prediction of nutrient digestibility and energy concentrations in fresh grass using nutrient composition. J Dairy Sci 2015;98:325773. https://doi.org/10.3168/jds.2014-8587
3. Brito AF, Tremblay GF, Bertrand A, et al. Alfalfa cut at sundown and harvested as baleage improves milk yield of latelactation dairy cows. J Dairy Sci 2008;91:3968-82. https:// doi.org/10.3168/jds.2008-1282

4. Molano G, Clark H. The effect of level of intake and forage quality on methane production by sheep. Aust J Exp Agric 2008;48:219-22. https://doi.org/10.1071/EA07253

5. Pathak AK. Various factors affecting microbial protein synthesis in the rumen. Vet World 2008;1:186-9.

6. Wang CM, Zhao YG, Aubry A, Arnott G, Hou FJ, Yan T. Effects of concentrate Input on nutrient utilization and methane emissions of two breeds of ewe lambs fed fresh ryegrass. Translational Anim Sci 2019;3:485-92. https://doi. org/10.1093/tas/txy106

7. Kim EJ, Newbold CJ, Scollan ND. Effect of water-soluble carbohydrate in fresh forage on growth and methane production by growing lambs. In: Proceedings of the 8th International Symposium on the Nutrition of Herbivores; 2011 Sep 6-9; Aberystwyth, Wales, UK. Cambridge University Press; 2011. pp. 270.

8. Miller LA, Moorby JM, Davies DR, et al. Increased concentration of water-soluble carbohydrate in perennial ryegrass (Lolium perenne L.): milk production from late-lactation dairy cows. Grass Forage Sci 2001;56:383-94. https://doi.org/10. 1046/j.1365-2494.2001.00288.x

9. Lee MRF, Merry RJ, Davies DR, et al. Effect of increasing availability of water-soluble carbohydrates on in vitro rumen. Anim Feed Sci Technol 2003;104:59-70. https://doi.org/10. 1016/S0377-8401(02)00319-X

10. Hoekstra NJ, Schulte RPO, Struik PC, Lantinga EA. Pathways to improving the $\mathrm{N}$ efficiency of grazing bovines. Eur J Agron 2007;26:363-74. https://doi.org/10.1016/j.eja.2006.12.002

11. Staerfl SM, Amelchanka SL, Kälber T, Soliva CR, Kreuzer M, Zeitz JO. Effect of feeding dried high-sugar ryegrass ('Aber Magic') on methane and urinary nitrogen emissions of primiparous cows. Livest Sci 2012;150:293-301. https://doi.org/ 10.1016/j.livsci.2012.09.019

12. Ellis JK, Dijkstra J, France J, et al. Effect of high-sugar grasses on methane emissions simulated using a dynamic model. J Dairy Sci 2012;95:272-85. https://doi.org/10.3168/jds.20114385

13. Brito AF, Tremblay GF, Lapierre H, et al. Alfalfa cut at sundown and harvested as baleage increases bacterial protein synthesis in late-lactation dairy cows. J Dairy Sci 2009;92:1092-107. https://doi.org/10.3168/jds.2008-1469

14. Smit HJ, Elgersma A. Diurnal fluctuations in vertical distribution of chemical composition in perennial ryegrass (Lolium perenne L.) sward during the season. In: Proceedings of the 20th General Meeting of the European Grassland Federation, 2004; Lucerne, Switzerland. p. 951-3.

15. Delagarde R, Peyraud JL, Delaby L, Faverdin P. Vertical distribution of biomass, chemical composition and pepsin-- 
cellulase digestibility in a perennial ryegrass sward: interaction with month of year, regrowth age and time of day. Anim Feed Sci Technol 2000;84:49-68. https://doi.org/10.1016/ S0377-8401(00)00114-0

16. Menke KH, Steingass $\mathrm{H}$. Estimation of the energetic feed value obtained from chemical analysis and in vitro gas production using rumen fluid. Anim Res Dev 1988;28:7-55.

17. Van Soest PJ, Wine RH. Use of detergents in the analysis of fibrous feeds. IV. Determination of plant cell wall constituents. J Assoc Official Anal Chem 1967;50:50-5. https://doi.org/10. 1093/jaoac/50.1.50

18. Thomas TA. An automated procedure for the determination of soluble carbohydrates in herbage. J Sci Food Agric 1977; 28:639-42. https://doi.org/10.1002/jsfa.2740280711

19. Schofield P, Pitt RE, Pell AN. Kinetics of fiber digestion from in vitro gas production. J Anim Sci 1994;72:2980-91. https:// doi.org/10.2527/1994.72112980x

20. Niderkorn VJ, Kim EJ, Hou FJ, Newbold CJ, Scollan ND. Methane production and microbial profile in the rumen from three high water-soluble carbohydrate perennial ryegrass monocultures differing in their heading dates using RUSITEC, In Proceedings of the XIth International Symposium on Ruminant Physiology; 2009 Sep 6-9; Clermont-Ferrand, France. p. 296-7.

21. Pelletier S, Tremblay GF, Bélanger G, et al. Forage nonstructural carbohydrates and nutritive value as affected by time of cutting and species. Agron J 2010;102:1388-98. https://doi. org/10.2134/agronj2010.0158

22. Morin C, Bélanger G, Tremblay GF, et al. Short Communication: Diurnal variations of nonstructural carbohydrates and nutritive value in timothy. Can J Plant Sci 2012;92:8837. https://doi.org/10.4141/cjps2011-272

23. Lechtenberg VL, Holt DA, Youngberg HW. Diurnal variation in nonstructural carbohydrates, in vitro digestibility, and leaf to stem ratio of alfalfa. Agron J 1971;63:719-24. https://doi. org/10.2134/agronj1971.00021962006300050019x

24. Youngberg HW, Holt DA, Lechtenberg VL. Diurnal variation in nitrogenous constituents of alfalfa (Medicago sativa L.). Agron J 1972;64:288-91. https://doi.org/10.2134/agronj1972. 00021962006400030010x

25. Burner DM, Belesky DP. Diurnal effects on nutritive value of alley-cropped orchardgrass herbage. Crop Sci 2004;44:
1776-80. https://doi.org/10.2135/cropsci2004.1776

26. Alende M. Evaluation of high sugar ryegrass varieties [Thesis]. Clemson, SC, USA: Clemson University; 2016.

27. Fanchone A, Nozière P, Portelli J, Duriot B, Largeau V, Doreau $M$. Effects of nitrogen underfeeding and energy source on nitrogen ruminal metabolism, digestion, and nitrogen partitioning in dairy cows. J Anim Sci 2013;91:895-906. https:// doi.org/10.2527/jas.2012-5296

28. McDonald P, Edwards RA, Greenhalgh JFD, Morgan CA, Sinclair LA, Wilkerson RG. Animal nutrition. 7th rev. ed. Essex. London, UK: Pearson Education Limited; 2011.

29. Tang SX, Tayo GO, Tan ZL, et al. Effects of yeast culture and fibrolytic enzyme supplementation on in vitro fermentation characteristics of low-quality cereal straws. J Anim Sci 2007; 86:1164-72. https://doi.org/10.2527/jas.2007-0438

30. Lovett DK, McGilloway D, Bortolozzo A, et al. In vitro fermentation patterns and methane production as influenced by cultivar and season of harvest of Lolium perenne L. Grass Forage Sci 2006;61:9-21. https://doi.org/10.1111/j.1365-2494. 2006.00500.x

31. Muck RE, Filya I, Contreras-Govea FE. Inoculant effects on alfalfa silage: in vitro gas and volatile fatty acid production. J Dairy Sci 2007;90:5115-25. https://doi.org/10.3168/jds.2006878

32. Yáñez-Ruiz DR, Bannink A, Dijkstra J, et al. Design, implementation and interpretation of in vitro batch culture experiments to assess enteric methane mitigation in ruminantsa review. Anim Feed Sci Technol 2016;216:1-18. https://doi. org/10.1016/j.anifeedsci.2016.03.016

33. AFRC (Agricultural and Food Research Council). Energy and protein requirements for ruminants. Wallingford, UK: CAB International; 1993.

34. Castillo AR, Kebreab E, Beever DE, et al. The effect of protein supplementation on nitrogen utilization in lactating dairy cows fed grass silage diets. J Anim Sci 2001;79:247-53. https:// doi.org/10.2527/2001.791247x

35. Hynes DN, Stergiadis S, Gordon A, Yan T. Effects of crude protein level in concentrate supplements on animal performance and nitrogen utilization of lactating dairy cows fed fresh-cut perennial grass. J Dairy Sci 2016;99:8111-20. https:// doi.org/10.3168/jds.2016-11110 